\title{
EDUKASI TANAMAN BERKHASIAT OBAT PADA PELAJAR MAN 2 CIREBON DESA BABAKAN KECAMATAN CIWARINGIN
}

\author{
Raden Bayu Indradi', Ferry Ferdiansyah Sofian', Ami Tjitraresmi', Ade Zuhrotun ${ }^{1,3}$, Imam Adi \\ Wicaksono $^{2}$, Zelika Mega Ramadhania ${ }^{1}$, dan Moelyono Moektiwardoyo ${ }^{1}$ \\ ${ }^{1}$ Departemen Biologi Farmasi, Fakultas Farmasi Universitas Padjadjaran \\ ${ }^{2}$ Departemen Farmakologi dan Farmasi Klinik, Fakultas Farmasi, Universitas Padjadjaran \\ ${ }^{3}$ Pusat Studi Pengembangan Pembelajaran, Fakultas Farmasi, Universitas Padjadjaran \\ E-mail: bayu.indradi@unpad.ac.id
}

\begin{abstract}
ABSTRAK. Tanaman obat merupakan salah satu kekayaan alam Indonesia. Pengetahuan mengenai tanaman obat berkhasiat seyogyanya perlu dimiliki oleh masyarakat Indonesia sejak usia muda agar kelak masyarakat dapat memanfaatkan tanaman obat berdasarkan pengetahuan yang sudah dimiliki. Berdasarkan pengamatan, daerah desa Babakan merupakan daerah pesantren dengan jumlah santri yang cukup banyak, berasal dari berbagai daerah di Indonesia. Edukasi tentang tanaman obat diharapkan dapat meningkatkan pengetahuan para santri kedepannya untuk memanfaatkan tanaman obat secara tepat, terutama pengobatan tradisional menggunakan herbal cukup populer di kalangan umat beragama. Edukasi dilakukan dengan pemetaan sasaran, koordinasi, dan penyampaian materi edukasi dan aplikasi digital mengenai informasi tanaman obat di MAN 2 Cirebon. Kegiatan ini bekerjasama dengan pihak sekolah MAN 2 Cirebon. Hasil dari kegiatan penyuluhan ini, siswa MAN 2 Cirebon dapat menjawab 10 jenis tanaman obat beserta manfaatnya dibandingkan sebelum penyuluhan yang hanya mengetahui 2-3 jenis tanaman dan manfaatnya. Dapat disimpulkan bahwa penyuluhan berlangsung efektif dan meningkatkan pengetahuan siswa MAN 2 Cirebon mengenai berbagai macam tanaman obat.
\end{abstract}

Kata kunci: Babakan; Cirebon; MAN; edukasi; tanaman obat

ABSTRACT. Medicinal plants are one of Indonesia's natural wealth. Knowledge of nutritious medicinal plants should be owned by Indonesian people at a young age so that they can later be used. Based on observations, the Babakan village area is a boarding school area with a large number of students, coming from various regions in Indonesia. Education about medicinal plants is expected to increase the knowledge of the students to use medicines appropriately, especially traditional medicines using herbs which are quite popular among religious people. Education is carried out by mapping targets, coordinating, and delivering educational material at Islamic Senior High School 2 Cirebon. As the result, after the education the students could identify 10 medicinal plants with their medicinal properties, while, before the education, they only knew 2-3 medicinal plants and the medicinal properties of the plants. It suggested that education took place effectively and improved the knowledge of Islamic Senior High School 2 Cirebon students about medicinal plants.

Key words: Babakan; Cirebon; Islamic Senior High School; education, medicinal plant

\section{PENDAHULUAN}

Peningkatan kesadaran, kemauan, dan kemampuan hidup sehat bagi setiap orang agar terwujud derajat kesehatan masyarakat yang setinggi-tingginya merupakan tujuan dari pembangunan kesehatan Indonesia. Kesehatan merupakan investasi untuk pembangunan sumber daya manusia yang produktif secara sosial dan ekonomi.

Upaya peningkatan kesehatan ini diselenggarakan dalam bentuk kegitan dengan pendekatan promotif, preventif, kuratif, dan rehabilitatifyang berkesinambungan, diantaranya memanfaatkan tanaman berkhasiat obat. Hasil riset kesehatan dasar (RISKESDAS) 2010 menunjukkan bahwa penggunaan obat tradisional pada masyarakat Indonesia meningkat pesat, sebanyak $59,12 \%$ pada semua umur, baik laki-lakimaupun perempuan dipedesaan maupun perkotaan pernah mengonsumsi obat tradisional. Presentase tanaman obat yang paling banyak digunakan secara berturutturut adalah jahe $(50,36 \%)$, kencur $(48,77 \%)$, temulawak $(39,65)$, meniran $(13,93 \%)$, dan mengkudu $(11,17 \%)$. Selain itu, ada $72,51 \%$ masyarakat yang menggunakan tanaman obat jenis lainnya. Berdasarkan data tersebut, banyaknya masyarakat yang memanfaatkan tanaman obat harus diikuti dengan edukasi dan pengetahuannya sedari muda sehingga diharapkan masyarakat dapat memanfaatkan tanaman obat secara tepat dan aman. Selain itu, salah satu keuntungan mempelajari tanaman obat sedari muda adalah pemahaman tentang tanaman obat akan lebih luas dan matang seiring waktu belajar yang panjang. Jika baru mulai dipelajari pada saat perkuliahan, dengan banyaknya jumlah tanaman obat di Indonesia dan pendeknya waktu studi, akan mengakibatkan kurangnya pemahaman terhadap tanaman obat.

Tingginya minat masyarakat terhadap obat tradisional juga disebabkan oleh biaya yang murah dan mudah dipraktikkan sendiri. Pengobatan menggunakan tumbuhan secara tradisional umumnya tidak menimbulkan efek samping yang berarti seperti yang sering terjadi pada pengobatan kimiawi. Selain itu, sebagian tumbuhan berkhasiat telah banyak ditanam oleh masyarakat, terutama di daerah pedesaan (Latief, 2009).

Pada era digital, informasi sangat mudah didapatkan dari berbagai sumber di internet, tidak terkecuali informasi-informasi mengenai tanaman obat serta manfaatnya. Seringkali, informasi yang beredar tidak dapat dipertanggungjawabkan sumbernya dan banyak yang sifatnya hanya sebagai sarana promosi suatu produk sehingga informasi tersebut menjadi bias. Bahkan, Kementerian Komunikasi dan Informatika menyebutkan 
saat ini terdeteksi ada 800.000 situs penyebar hoaks, dan bukan tidak mungkin salah satunya memiliki konten tanaman obat yang dapat menyesatkan (Yuliani, 2017). Maka dari itu, masyarakat perlu mempunyai akses kepada informasi tanaman obat yang dapat dipertanggungjawabkan sumbernya, dan mudah diakses dari gawai pribadi sehingga dapat diakses dimanapun dan kapanpun.

\section{METODE}

Kegiatan Pengabdian Pada Masyarakat terintregasi Hibah Internal UNPAD dilaksanakan di MAN 2 Cirebon, Kecamatan Ciwaringin. Metode edukasi yang digunakan meliputi beberapa tahapan kerja, diantaranya adalah pengembangan media aplikasi tanaman obat melalui riset, koordinasi dengan perangkat sekolah, penyiapan media booklet, pelaksanaan kegiatan edukasi, dan evaluasi hasil kegiatan.

Tahap pengembangan aplikasi dilakukan melalui riset dari tim berkaitan dengan pengumpulan informasi serta pengembangan aplikasi. Tahapan koordinasi dilakukan oleh dosen bersama dengan mahasiswa dengan berkunjung ke MAN 2 Cirebon dan berkoodinasi langsung dengan guru MAN 2 Cirebon. Kemudian, dilakukan penentuan sasaran serta waktu pelaksanaan. Selanjutnya, dilakukan penyiapan media booklet dengan memilih informasi-informasi dari beberapa jenis tumbuhan terpilih yang akan disampaikan pada kegiatan edukasi. Booklet ini digunakan sebagai media bantu untuk memudahkan para siswa memahami penyampaian tentang edukasi tanaman obat. Pelaksanaan dilakukan dengan penyampaian materi pendahuluan tentang tanaman obat dan mengenal tumbuhan berkhasiat obat. Pengumpulan data dilakukan dengan pembagian kuesioner ke peserta edukasi yakni siswa/siswi MAN 2 Cirebon.

\section{HASIL DAN PEMBAHASAN}

Pengabdian pada masyarakat berupa edukasi tanaman berkhasiat obat pada pelajar SMA/Aliyah merupakan pengabdian pada masyarakat oleh tim yang terdiri dari dosen dan mahasiswa. Pada tahap awal, dilaksanakan riset mengenai pembuatan Sistem Informasi Tanaman Obat Bermanfaat (STOMATA). Sistem ini dibuat berbasis website dan aplikasi android sehingga seluruh informasi tanaman obat yang ada di database dapat diakses oleh pengguna melalui gawai masingmasing. Sistem informasi ini dibuat untuk menghimpun informasi-informasi dan data-data yang valid mengenai tanaman obat agar dapat dimanfaatkan secara tepat dan bertanggungjawab.

Selanjutnya, koordinasi dilakukan dengan survey ke lokasi MAN 2 Cirebon di Desa Babakan, Kecamatan Ciwaringin, Kabupaten Cirebon bersama tim dosen dan mahasiswa KKN. Survey ke lapangan dilakukan untuk meninjau lokasi pelaksanaan edukasi, selanjutnya dilakukan koordinasi dengan guru MAN untuk menentukan sasaran siswa yang tepat karena di MAN 2 Cirebon terdapat 2 kelas, yaitu kelas reguler dan kelas full day. Kelas reguler berjumlah kurang lebih 1000 siswa terdiri dari kelas X, XI, dan XII. Sementara, kelas full day berjumlah lebih sedikit yaitu kurang lebih 190 siswa yang terdiri dari kelas $\mathrm{X}$, XI, dan XII. Berdasarkan diskusi dengan guruguru MAN 2 Cirebon, dipilih kelas full day sebagai peserta edukasi dengan pertimbangan siswa reguler sudah memiliki jadwal yang padat hingga akhir tahun. Secara pembelajaran, yang membedakan antara siswa full day dengan reguler hanya jam belajarnya, dimana siswa reguler selesai pembelajaran hingga siang hari pukul 12.00 sementara siswa full day menyelesaikan pembelajaran di jam 16.00 sore hari.

Selanjutnya penyiapan media booklet, dilakukan dengan memilih informasi tanaman-tanaman obat yang umum dijumpai dan sering digunakan masyarakat Indonesia karena tujuan dari PPM ini sendiri adalah untuk mengedukasi dan mengenalkan tanaman-tanaman obat pada siswa SMA/Aliyah. Diharapkan dengan mengenal dan memiliki pengetahuan tentang tanaman obat, akan dapat meningkatkan kesadaran maupun keinginan masyarakat menggunakan tanaman obat untuk berbagai manfaat kesehatan.

Selanjutnya pada penyelenggaraan kegiatan edukasi di MAN 2 Cirebon, diikuti oleh siswa full day sejumlah 190 orang yang terdiri dari siswa kelas X - XI - XII. Kegiatan ini dilangsungkan di aula MAN 2 Cirebon, Desa Babakan, Kecamatan Ciwaringin, Kabupaten Cirebon. Edukasi diawali dengan penyampaian materi mengenai obat herbal, penggolongannya, dan jenis-jenisnya. Pada sesi ini, disampaikan mengenai apa yang dimaksud dengan obat tradisional, bagaimana penggolongan obat tradisional berdasarkan regulasi yang ada, kemudian bagaimana cara pembuatan obat tradisional. Materi ini diberikan agar para siswa mengenal jenis-jenis obat tradisional yang beredar dan dapat dibeli di apotik maupun toko obat, sehingga para siswa dapat memilih dan mengetahui mana obat herbal yang baik dan aman untuk dikonsumsi.

Kemudian, dilakukan penyampaian materi mengenai pengenalan berbagai tanaman obat. Pada sesi ini, disampaikan mengenai bagian-bagian tanaman yang dapat dimanfaatkan sebagai obat karena perbedaan bagian tanaman yang digunakan dapat berbeda khasiat yang diberikan oleh tanaman tersebut. Untuk itu, siswa diedukasi mengenai berbagai bagian tanaman yang biasa digunakan untuk pengobatan. Kemudian, siswa dikenalkan dengan 10 tanaman obat yang umum digunakan di Indonesia, yaitu jambu biji, kayu putih, rosella, jahe, kumis kucing, kunyit, manggis, sambiloto, kencur, dan seledri. Pengenalan tanaman ini meliputi nama latin, bagian tanaman yang digunakan, dan manfaat kesehatan yang diberikan. Selain itu, pengenalan 10 tanaman obat ini 
juga mewakili berbagai bagian tanaman, antara lain daun (jambu biji, kumis kucing, dan kayu putih), rimpang (jahe, kunyit, kencur), bunga (rosella), kulit buah (manggis), dan herba (sambiloto dan seledri). Sesi ini berjalan dengan sangat interaktif dan para siswa terlihat sangat antusias. Beberapa siswa menyampaikan pengalamannya ketika menggunakan suatu tumbuhan obat dan mengaku baru mengetahui manfaat yang dimiliki dari tanaman tersebut. Hasil dari edukasi tersebut kemudian dievaluasi dengan kuesioner yang diisi oleh peserta. Hasil menunjukkan peningkatan wawasan siswa mengenai tanaman obat, dari observasi awal rata-rata hanya dapat menyebutkan 2-3 jenis tanaman obat tanpa mengetahui manfaatnya bagi kesehatan hingga dapat menjawab 10 tanaman obat beserta manfaatnya setelah edukasi. Data awal (Base line) peserta yang cukup rendah dapat dipahami, karena 22,6\% dari peserta sama sekali belum pernah menggunakan tanaman obat untuk mengobati penyakit dan 77,4\% yang pernah menggunakan tanaman obat, rata-rata hanya 1-2 tanaman saja yang pernah dimanfaatkan. Meningkatnya wawasan siswa setelah edukasi ini, dimungkinkan karena penyampaian edukasi yang interaktif dan dibantu dengan media booklet. Booklet yang dibagikan kepada setiap peserta memberikan gambaran kepada siswa mengenai materi yang disampaikan. Sementara, materi disampaikan dalam bentuk permainan tebak tepat tanaman obat, dimana para siswa diberikan petunjuk yang informasinya dapat mereka cari di booklet. Setelah terjawab, dilakukan pembahasan mengenai tanaman obat tersebut. Indikator keberhasilan ini dapat dilihat pada tabel 1.

Tabel 1. Indikator Keberhasilan Program PPM

\begin{tabular}{|c|c|c|c|}
\hline No. & Indikator & Base Line & Pencapaian \\
\hline 1. & $\begin{array}{l}\text { Pengetahuan } \\
\text { tentang } \\
\text { tanaman } \\
\text { yang dapat } \\
\text { dimanfaatkan } \\
\text { untuk kesehatan }\end{array}$ & $\begin{array}{l}\text { Siswa dapat } \\
\text { menyebutkan 2-3 } \\
\text { jenis tanaman yang } \\
\text { dapat dimanfaatkan } \\
\text { untuk kesehatan }\end{array}$ & $\begin{array}{l}\text { Siswa dapat } \\
\text { menyebutkan } \\
\text { minimal } 10 \\
\text { jenis tanaman } \\
\text { yang dapat } \\
\text { dimanfaatkan } \\
\text { untuk kesehatan }\end{array}$ \\
\hline 2. & $\begin{array}{l}\text { Pengetahuan } \\
\text { tentang manfaat } \\
\text { kesehatan dari } \\
\text { tanaman obat }\end{array}$ & $\begin{array}{l}\text { Siswa hanya } \\
\text { mengetahui } 1-2 \\
\text { manfaat kesehatan } \\
\text { dari tanaman obat } \\
\text { beserta contohnya }\end{array}$ & $\begin{array}{l}\text { Siswa dapat } \\
\text { mengetahui } \\
\text { minimal } \\
10 \text { manfaat } \\
\text { kesehatan dari } \\
\text { tanaman obat } \\
\text { beserta jenisnya }\end{array}$ \\
\hline 3. & Antusiasme & $\begin{array}{l}\text { Para siswa belum } \\
\text { menaruh minat } \\
\text { terhadap tanaman } \\
\text { obat. }\end{array}$ & $\begin{array}{l}\text { Banyaknya } \\
\text { peserta yang } \\
\text { meminta } \\
\text { penyuluhan } \\
\text { dengan tema } \\
\text { beragam } \\
\text { yang masih } \\
\text { berhubungan } \\
\text { dengan tanaman } \\
\text { obat }\end{array}$ \\
\hline
\end{tabular}

Kemudian, siswa-siswa MAN 2 Cirebon juga diperkenalkan suatu aplikasi digital yang tengah dikembangkan oleh tim riset. Pengenalan aplikasi ini bertujuan untuk membantu siswa-siswi mewadahi rasa keingintahuan masing-masing untuk mencari informasi tentang tanaman obat. Adanya aplikasi ini akan membantu siswa-siswi mendapatkan informasi tentang tanaman obat yang dapat dipertanggungjawabkan. Untuk itu, pengenalan ini dilakukan sebagai bentuk edukasi penggunaan media digital untuk pencarian informasi yang kredibel dan dapat dipertanggungjawabkan.

\section{SIMPULAN}

Pelaksanaan program PPM dengan kegiatan edukasi tanaman berkhasiat obat pada pelajar SMA/Aliyah dapat terlaksana dengan efektif atas kerjasama berbagai pihak. Setelah kegiatan edukasi ini, dapat disimpulkan terjadi peningkatan pengetahuan siswasiswi MAN 2 Cirebon mengenai tanaman berkhasiat obat.

\section{DAFTAR PUSTAKA}

Badan Penelitian dan Pengembangan Kesehatan Kementrian Kesehatan RI. (2010). Riset Kesehatan Dasar (Riskesdas 2010), Kementrian Kesehatan Republik Indonesia. Jakarta.

Latief, Abdul. (2009). Obat Tradisional. Penerbit Buku Kedokteran EGC. Jakarta.

Menkes RI. (2016). Peraturan Menteri Kesehatan Republik Indonesia Nomor 6 Tahun 2016 Tentang Formularium Obat Herbal Asli Indonesia. Kementerian Kesehatan Republik Indonesia. Jakarta.

Menkes RI. (2017). Keputusan Menteri Kesehatan Republik Indonesia Nomor HK. 01.07/ MENKES/187/2017 Tentang Formularium Ramuan Obat Tradisional Indonesia. Kementrian Kesehatan Republik Indonesia. Jakarta.

Yan MC, Jun P, Liang F. (2007). The Mode of Field Practice of Botany. J Journal of Shenyang Normal University: Natural Science Edition. 25(2); 286288.

Yuliani, Ayu. (2017). Ada 800.000 situs penyebar hoaks di Indonesia. (https://kominfo.go.id/content/ detail/12008/ada-800000-situs-penyebar-hoax-diindonesia/0/sorotan_media, diakses 12 Desember 2018). 